Check for updates

Cite this: Chem. Sci., 2018, 9, 4873

\title{
Ruthenium-catalyzed umpolung carboxylation of hydrazones with $\mathrm{CO}_{2} \dagger$
}

\author{
Si-Shun Yan, ${ }^{a}$ Lei Zhu, ${ }^{b}$ Jian-Heng Ye, ${ }^{a}$ Zhen Zhang, ${ }^{a}$ He Huang, ${ }^{a}$ Huiying Zeng, (D) \\ Chao-Jun Li, (DD*cd Yu Lan (iD) *b and Da-Gang Yu (iD) *ae
}

The first ruthenium-catalyzed umpolung carboxylation of hydrazones with $\mathrm{CO}_{2}$ to generate important aryl acetic acids is reported. Besides aldehyde hydrazones, a variety of ketone hydrazones, which have not been successfully applied in previous umpolung reactions with other reactive electrophiles, also show high reactivity and selectivity under mild conditions. Moreover, this operationally simple protocol features good functional group tolerance, is readily scalable, and offers easy derivation of important structures, including bioactive felbinac and adiphenine. Computational studies reveal that this umpolung reaction proceeds through the generation of a Ru-nitrenoid followed by concerted [4 +2] cycloaddition with $\mathrm{CO}_{2}$.

Received 20th March 2018

Accepted 27th April 2018

DOI: $10.1039 / \mathrm{c} 8 \mathrm{sc} 01299 \mathrm{~g}$

rsc.li/chemical-science

\section{Introduction}

Carbon dioxide $\left(\mathrm{CO}_{2}\right)$ has attracted significant attention as an ideal C1 source due to its high abundance, low cost, low toxicity and renewability. ${ }^{\mathbf{1}}$ In numerous chemical transformations involving $\mathrm{CO}_{2},{ }^{2}$ the synthesis of carboxylic acids through $\mathrm{C}-\mathrm{C}$ bond formation is highly promising..$^{3-5}$ Given that aryl acetic acids are present in myriad natural products, agrochemicals and drugs (Fig. 1), ${ }^{6}$ great effort has been devoted to the synthesis of this motif following various strategies. ${ }^{7,8}$ Notably, the transition metal-catalyzed reductive carboxylation of benzyl (pseudo)halides with $\mathrm{CO}_{2}$ has been well documented by Martin
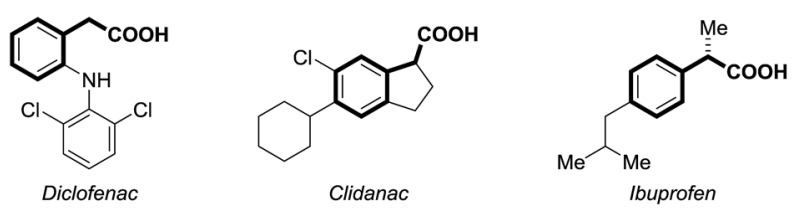

Fig. 1 Aryl acetic acid-containing drugs.

${ }^{a}$ Key Laboratory of Green Chemistry \& Technology of Ministry of Education, College of Chemistry, Sichuan University, 29 Wangjiang Road, Chengdu 610064, P. R. China. E-mail:dgyu@scu.edu.cn

${ }^{b}$ School of Chemistry and Chemical Engineering, Chongqing University, Chongqing 400030, P. R. China. E-mail: lanyu@cqu.edu.cn

${ }^{c}$ The State Key Laboratory of Applied Organic Chemistry, Lanzhou University, Lanzhou 730000, P. R. China

${ }^{d}$ Department of Chemistry and FQRNT Centre for Green Chemistry and Catalysis, McGill University, 801 Sherbrooke St. W., Montreal, Quebec H3A OB8, Canada. E-mail:cj.li@mcgill.ca

${ }^{e}$ State Key Laboratory of Elemento-Organic Chemistry, Nankai University, Tianjin 300071, P. R. China

$\dagger$ Electronic supplementary information (ESI) available: Experimental details and characterization data. See DOI: 10.1039/c8sc01299g and He (Scheme 1a). ${ }^{8}$ However, the Ru-catalyzed carboxylation with $\mathrm{CO}_{2}$ has rarely been investigated and very limited success has been achieved. ${ }^{9}$ Herein, we report a novel Ru-catalyzed umpolung carboxylation of hydrazones with $\mathrm{CO}_{2}$ under mild conditions (Scheme 1b). This reaction features good functional group tolerance, high selectivity, broad substrate scope and facile scalability.

An umpolung strategy creates new reactivity by reversing the inherent polarity of common functional groups and consequently allowing for new reactions with distinct bond formations. ${ }^{10}$ Recently, transition-metal-free umpolung carboxylations of imines and derivatives with $\mathrm{CO}_{2}$ have been well developed by Sato, Radosevich and Zhang to generate $\alpha$-amino acids. ${ }^{11}$ In 2015, an elegant base-promoted Shapiro-type carboxylation of $\mathrm{N}$-tosylhydrazones to generate acrylic acids was reported by Cheng (Scheme 1b). ${ }^{\mathbf{1 2}}$ However, there is no report to generate important aryl acetic acids via the cleavage of $\mathrm{C}=\mathrm{N}$ double bonds with a catalytic system. As part of our continuing interest in advancing sustainable organic synthesis with $\mathrm{CO}_{2}{ }^{13}$ we wondered whether transition metal-catalysis could resolve such

a) Reductive carboxylation of benzyl (pseudo)halides with $\mathrm{CO}_{2}$ (Martin, $\mathrm{He}$ )
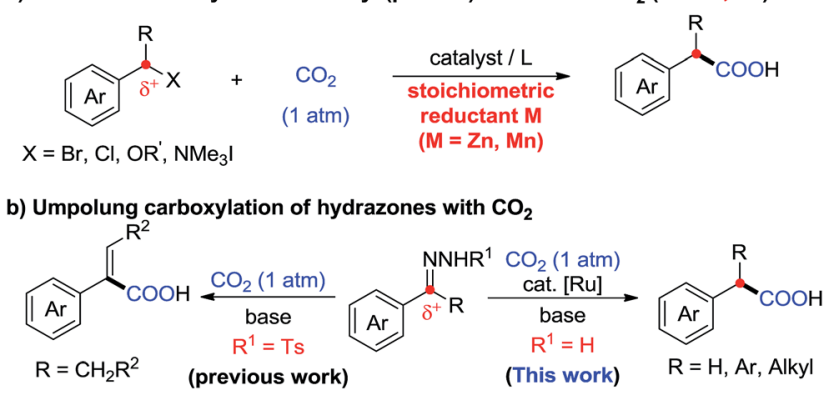

Shapiro-type carboxylation Selective Ru-catalyzed carboxylation

Scheme 1 Synthesis of aryl acetic acids with $\mathrm{CO}_{2}$. 
a challenge with different reaction mechanisms. Recently, one of us has developed Ru-catalyzed umpolung reactions with carbonyls as carbanion equivalents. ${ }^{\mathbf{1 4}}$ Considering that hydrazones are easily prepared from carbonyl compounds, which widely exist in nature and industry, this new strategy promises to be more sustainable and efficient for the synthesis of phenylacetic acids, especially for complex examples. At the outset of our investigations, however, it was unclear whether such a procedure could ever be implemented, since Ru-assisted Wolff-Kishner reduction ${ }^{\mathbf{1 5}}$ takes place smoothly under mild reaction conditions. The azine byproduct could also be easily generated from the hydrazones. Moreover, a possible side reaction of basepromoted Shapiro-type carboxylation of ketone hydrazones to acrylic acids may occur to compete with our designed reactions. $^{12}$

\section{Results and discussion}

With these challenges in mind, we began our study by evaluating the reaction of benzaldehyde hydrazone 1a with $\mathrm{CO}_{2}$ (Table 1). To our delight, we found that many diphosphine ligands could promote this reaction (entries 1-3) and dppf gave the best result (entry 3), which might arise from higher nucleophilicity of the in situ generated Ru-complex. We also tested a variety of bases and found that inorganic bases were superior to organic bases in this reaction (entries 3-6). Increasing or decreasing the amount of base gave a lower yield (entries 7 and 8). CsF served as an efficient additive to enhance the yield (entry 11), which might arise from enhanced nucleophilicity with the fluoride anion as a strong hydrogen bond acceptor. Control experiments demonstrated that the Ru-catalyst was vital to this

Table 1 Optimization of the reaction conditions ${ }^{a}$

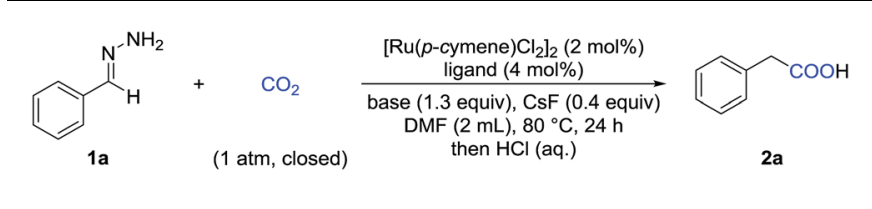

\begin{tabular}{llll}
\hline Entry & Ligand & Base & Yield $^{b}(\%)$ \\
\hline 1 & dppp & $\mathrm{Cs}_{2} \mathrm{CO}_{3}$ & 44 \\
2 & dppe & $\mathrm{Cs}_{2} \mathrm{CO}_{3}$ & 19 \\
3 & dppf & $\mathrm{Cs}_{2} \mathrm{CO}_{3}$ & $\mathbf{8 5}(\mathbf{8 3})$ \\
4 & dppf & $\mathrm{K}_{3} \mathrm{PO}_{4}$ & 51 \\
5 & dppf & $\mathrm{KO}^{t} \mathrm{Bu}$ & 80 \\
6 & dppf & $\mathrm{DBU}$ & 27 \\
$7^{c}$ & dppf & $\mathrm{Cs}_{2} \mathrm{CO}_{3}$ & 73 \\
$8^{d}$ & dppf & $\mathrm{Cs}_{2} \mathrm{CO}_{3}$ & 72 \\
9 & No & $\mathrm{Cs}_{2} \mathrm{CO}_{3}$ & 13 \\
10 & dppf & $\mathrm{No}$ & 31 \\
$11^{e}$ & dppf & $\mathrm{Cs}_{2} \mathrm{CO}_{3}$ & 78 \\
$12^{f}$ & dppf & $\mathrm{Cs}_{2} \mathrm{CO}_{3}$ & N.D. \\
$13^{g}$ & dppf & $\mathrm{Cs}_{2} \mathrm{CO}_{3}$ & N.D.
\end{tabular}

${ }^{a}$ Reaction conditions: $1 \mathrm{a}(0.4 \mathrm{mmol}){ }^{b}$ Yields were determined by crude ${ }^{1} \mathrm{H}$ NMR using dibromomethane as an internal standard, and the isolated yields are given in parentheses. ${ }^{c}$ Base $(0.4 \mathrm{mmol}) .{ }^{d}$ Base $(0.6$ mmol). ${ }^{e}$ No CsF. ${ }^{f}$ No $\left[\mathrm{Ru}(p \text {-cymene }) \mathrm{Cl}_{2}\right]_{2} \cdot{ }^{g} \mathrm{~N}_{2}$ instead of $\mathrm{CO}_{2} . \mathrm{DBU}=$ 1,8-diazabicyclo[5.4.0] undec-7-ene. N.D. $=$ not detected. transformation (entry 12) and that both the ligand and the base were important (entries 9 and 10). No desired product was detected in the absence of $\mathrm{CO}_{2}$ (entry 13).

With the optimized reaction conditions in hand, we then tested the scope of aldehyde hydrazones (Table 2), most of which were prepared from the corresponding aldehyde in one step and used without further purification, thus representing a significant advantage from a practical standpoint. Both electron-donating and electron-withdrawing groups on the phenyl ring were compatible. Different substituents at various positions on the arenes, including a bulky trifluoromethyl group at the ortho position (2r), did not hamper the reaction. Remarkably, a variety of functional groups, such as fluoro (2b), chloro (2c and $2 \mathbf{l}$ ), bromo (2d, $2 \mathbf{m}$ and $2 \mathbf{p}$ ), iodo (2e and $2 \mathbf{q})$, ether (2g, $\mathbf{2 j}$ and $\mathbf{2 k}$ ), ester (2i), nitro (2n), and cyano (2o), were all tolerated, providing a possibility for further transformations. Moreover, different kinds of fused rings (2s, 2t and 2u) and heterocycles, such as thiophene, benzothiophene and indole $(2 \mathbf{v}, 2 \mathbf{w}$ and $2 \mathbf{x})$, were compatible in this reaction. It is worth noting that a pharmaceutical agent felbinac (2f) and a known plant growth stimulant ( $2 \mathbf{w})$ were both prepared readily and in a good yield with our strategy.

Given that $\alpha$-substituted phenylacetic acids are present in a large collection of bioactive molecules, we wondered whether our procedure could be extended to ketone hydrazones, which have not been successfully applied in previous umpolung reactions with other reactive electrophiles. ${ }^{14}$ Although WolffKishner reduction was anticipated, we were delighted to discover that benzophenone hydrazone reacted smoothly to give the diphenylacetic acid $\mathbf{4 a}$ in $72 \%$ or $86 \%$ yield with minor modification of the reaction conditions (Table 3). Furthermore, the substrates with different substituents, including fluoro, chloro, and methoxyl, afforded the desired products in

Table 2 Substrate scope of (hetero)arylaldehyde hydrazones ${ }^{a}$

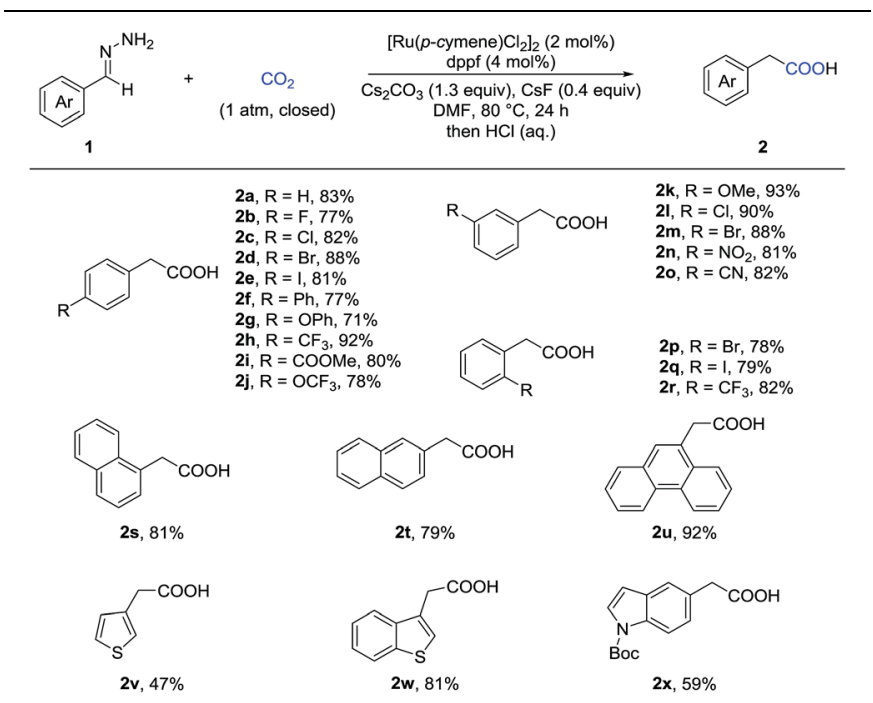

${ }^{a}$ Reaction conditions: $1(0.4 \mathrm{mmol}), 1 \mathrm{~atm}$ of $\mathrm{CO}_{2},\left[\mathrm{Ru}(p \text {-cymene }) \mathrm{Cl}_{2}\right]_{2}$ (0.008 mol), dppf $(0.016 \mathrm{mmol}), \mathrm{Cs}_{2} \mathrm{CO}_{3}(0.52 \mathrm{mmol}), \mathrm{CsF}(0.16$ $\mathrm{mmol})$, DMF $(2 \mathrm{~mL}), 80^{\circ} \mathrm{C}$, and $24 \mathrm{~h}$; isolated yields. 
Table 3 Substrate scope of ketone hydrazones ${ }^{a}$

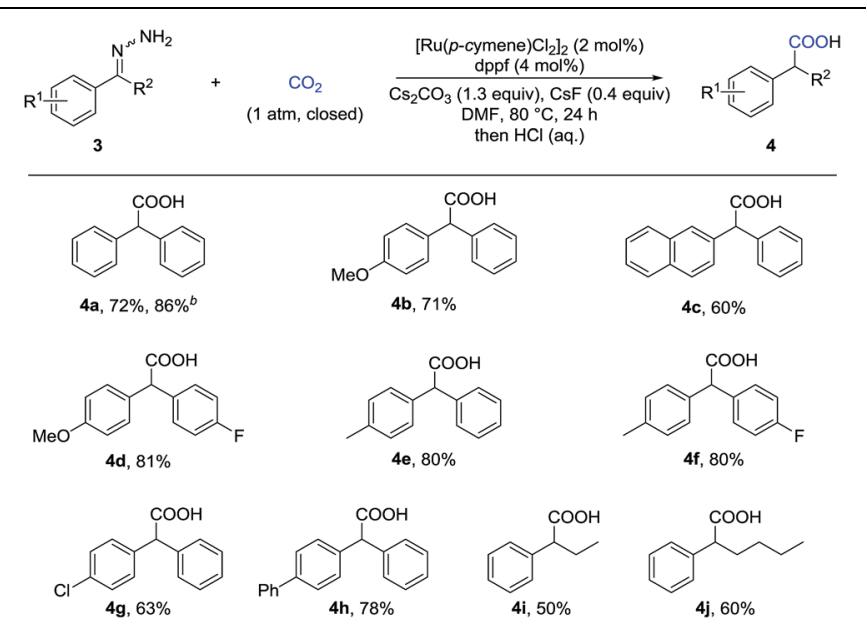

${ }^{a}$ The same reaction conditions as given in Table 2; isolated yields. ${ }^{b}$ Using $\mathrm{KO}^{t} \mathrm{Bu}$ (1.5 equiv.) instead of $\mathrm{Cs}_{2} \mathrm{CO}_{3}$ (1.3 equiv.) as a base.

moderate to good yields $(\mathbf{4 b}-\mathbf{4 h})$. Besides the benzophenone hydrazones, readily-available ketone hydrazones $\mathbf{3 i}$ and $\mathbf{3 j}$ furnished the corresponding $\alpha$-alkylphenylacetic acid products in synthetically useful yields, showing the further utility of this process.

To further demonstrate the utility of this umpolung carboxylation, we conducted a gram-scale synthesis of 3-bromophenylacetic acid $\mathbf{2 m}$ in $83 \%$ yield (Scheme 2). An antihyperlipidemic drug, fenofibrate $\mathbf{3} \mathbf{k}^{\prime}$, could be subjected to this method to produce the acid $\mathbf{4 k}$ in $60 \%$ isolated yield. Moreover, the product $\mathbf{4 a}$ was readily converted in one step to adiphenine (5), an inhibitor of the nicotinic receptor. ${ }^{16 a}$ The antiproliferative agent $\mathbf{6}$ and the known histone deacetylase inhibitor 7 were efficiently accessed by respective amidations in good yields (see the ESI $\dagger$ for details). ${ }^{\mathbf{1 6 b} \boldsymbol{b} \boldsymbol{d}}$

On the basis of preliminary mechanistic studies and previous reports, ${ }^{\mathbf{1 4}}$ a plausible mechanism is proposed to

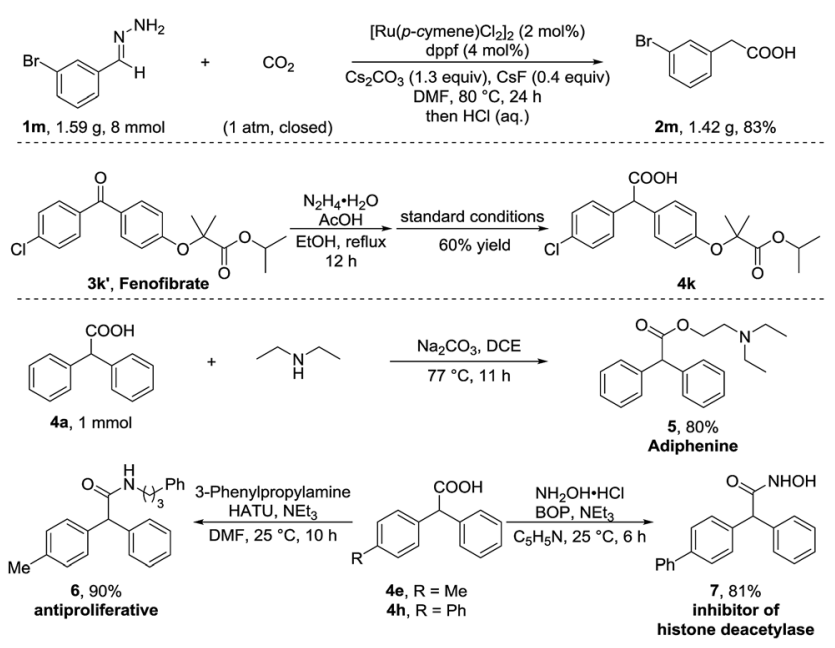

Scheme 2 Gram-scale synthesis and transformations. account for this transformation. As shown in Fig. 2, catalyst $\mathbf{A}$ could be generated (see the ESI $\uparrow$ for details) which undergoes ligand exchange with hydrazone and $\mathrm{Cs}_{2} \mathrm{CO}_{3}$ to give complex $\mathbf{B}$, which then undergoes two step deprotonation to generate a $\mathrm{Ru}$ nitrenoid complex D. ${ }^{17}$ After a concerted hetero-[4+2] cycloaddition with $\mathrm{CO}_{2}$, a six-membered Ru-cycle $\mathbf{E}$ can be formed. Then the release of $\mathrm{N}_{2}$, a driving force for this reaction, and the following protonation-ligand exchange provide the desired product and regenerate the active catalyst B. Alternatively, the intermediate $\mathbf{F}$ could also be generated from $\mathbf{D}$ via sequential isomerization, carbenation, and $\mathrm{CO}_{2}$ insertion (Path-B).

To further identify the proposed mechanism, a density functional theory (DFT) method M06-L was employed to investigate this reaction. ${ }^{18}$ The reactant $1 \mathrm{a}$ coordinated Ru carbonate species B was considered as a starting complex (see the Fig. $\mathrm{S} 1 \dagger$ for details). The first $\mathrm{N}-\mathrm{H}$ bond cleavage proceeds via a transition state 8-ts (Fig. S2 $\dagger$ ), with a free energy barrier of $23.9 \mathrm{kcal} \mathrm{mol}^{-1}$, to generate the amino-Ru intermediate $\mathbf{C}$. Subsequently, the second step deprotonation occurs rapidly with the assistance of $\mathrm{Cs}_{2} \mathrm{CO}_{3}$, leading to the formation of the Ru-nitrenoid intermediate $\mathbf{D}$.

After the formation of Ru-nitrenoid D, in Path-A (Fig. 3), the six-membered Ru-cycle complex $\mathbf{E}$ was obtained through an intermolecular hetero-[4+2] cycloaddition with $\mathrm{CO}_{2}$, with a free energy barrier of $22.4 \mathrm{kcal} \mathrm{mol}^{-1} .^{19}$ The subsequent $\mathrm{C}-\mathrm{N}$ bond cleavage leads to the generation of the benzylruthenium intermediate $\mathbf{F}$, which is exergonic by $34.1 \mathrm{kcal} \mathrm{mol}^{-1}$ as a result of $\mathrm{N}_{2}$ release. The phenylacetate $\mathbf{1 4}$ was then released after the following protonation-ligand exchange, and the active catalyst $\mathbf{B}$ was also concomitantly regenerated. Meanwhile, the calculation of activation free energy of Path-B has also been conducted. The

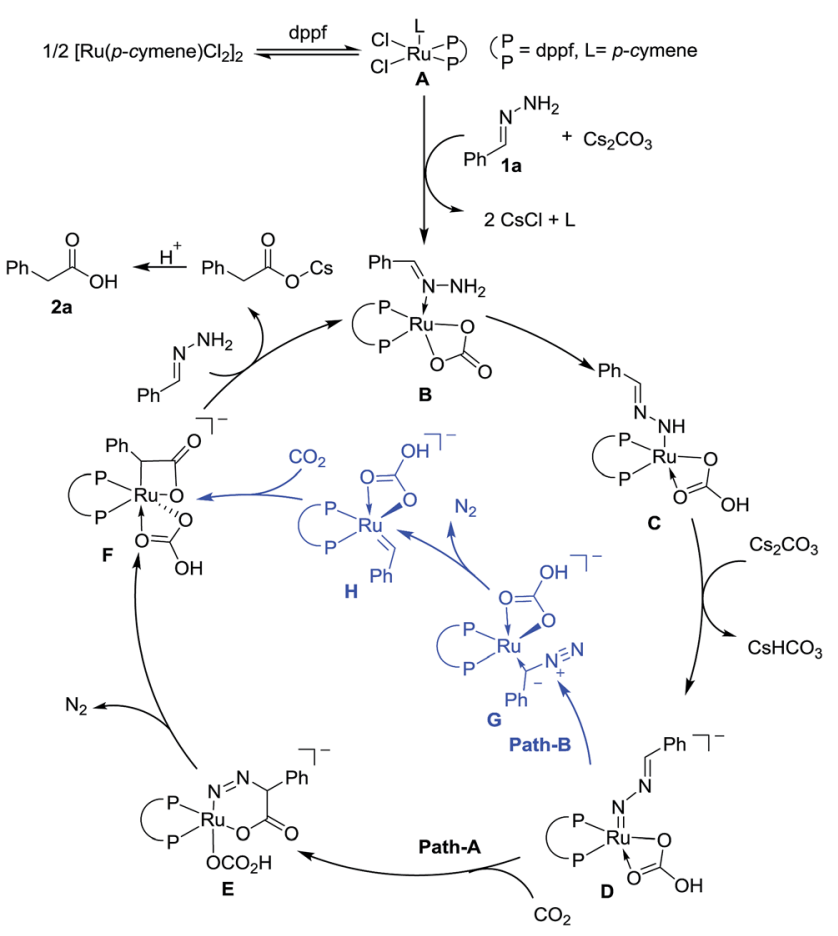

Fig. 2 Proposed mechanism 

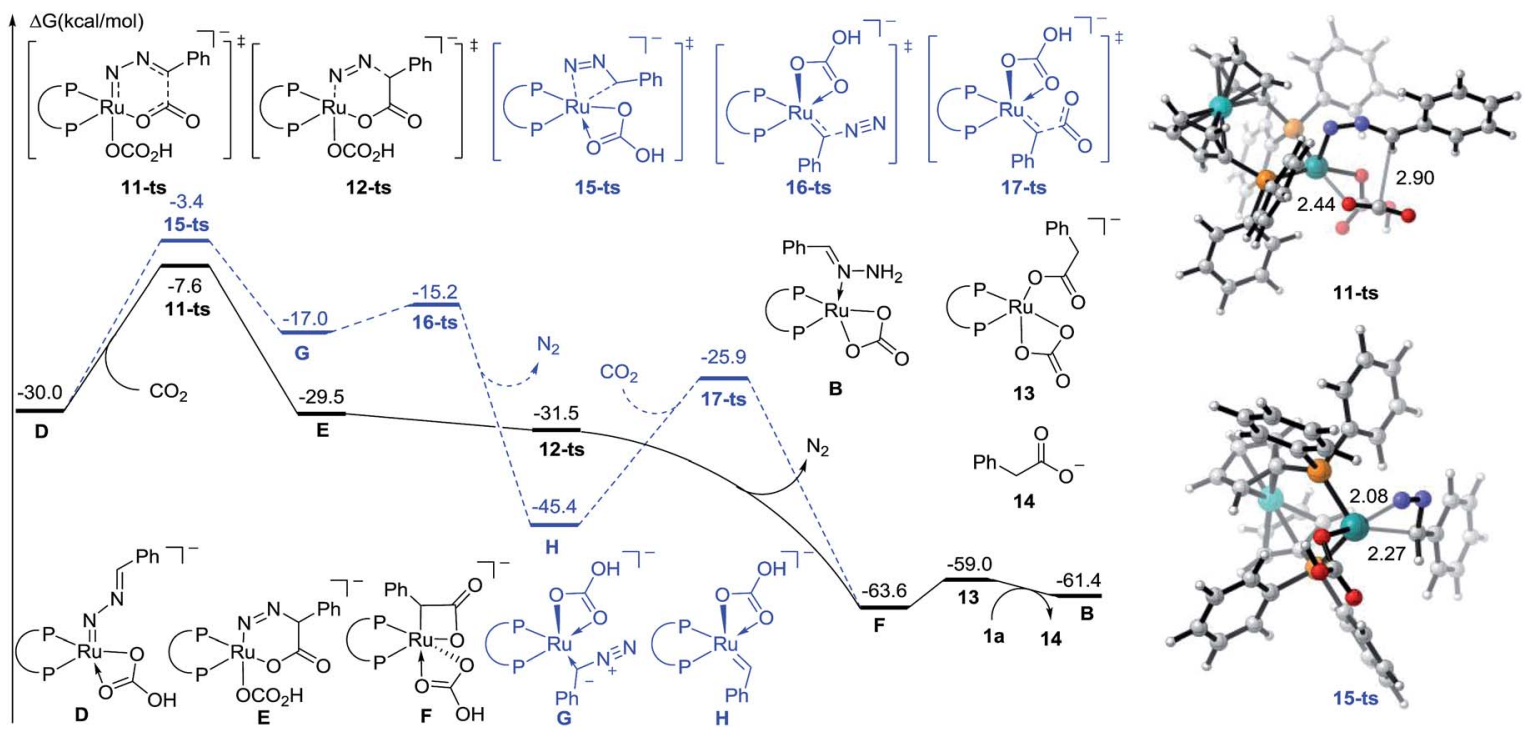

Fig. 3 Free energy profiles of Path-A (plain) and Path-B (dashed) for ruthenium-catalyzed carboxylation. The distances are represented in angstroms.

isomerization of the Ru-nitrenoid intermediate $\mathbf{D}$ could afford the diazoalkane-coordinated $\mathrm{Ru}$ complex $\mathbf{G}$, which is endergonic by $13.0 \mathrm{kcal} \mathrm{mol}^{-1}$. The subsequent carbenation could proceed rapidly to afford the Ru-carbenoid $\mathbf{H}$ with an energy barrier of $1.8 \mathrm{kcal} \mathrm{mol}^{-1} . \mathrm{CO}_{2}$ insertion via a transition state 17ts then generates the common benzylruthenium intermediate F. The overall activation free energy of Path-B is determined to be $26.6 \mathrm{kcal} \mathrm{mol}^{-1}$, which is $4.2 \mathrm{kcal} \mathrm{mol}^{-1}$ higher than that of the $[4+2]$ cycloaddition step in Path-A. Therefore, the carbenation pathway (Path-B) turns out to be unfavorable in comparison with Path-A.

Moreover, Fig. 4 shows the variation of the natural bond orbital (NBO ${ }^{20}$ atomic charges on benzylic carbon during the catalytic cycle. It demonstrates that the increasing of the electron density on benzylic carbon is accompanied by the two step $\mathrm{N}-\mathrm{H}$ cleavage, which clearly indicates the umpolung of the reactants. Thus, the Ru-nitrenoid $\mathbf{D}$ exhibits enhanced reactivity with $\mathrm{CO}_{2}$.

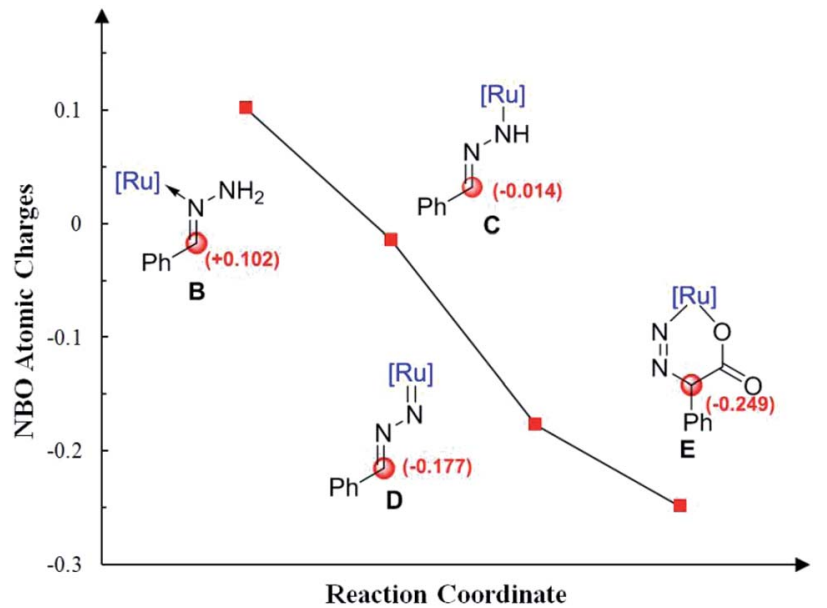

Fig. 4 Calculated NBO atomic charges on benzylic carbon during the catalytic cycle.

\section{Conclusions}

In summary, we have realized the first Ru-catalyzed umpolung carboxylation of hydrazones with $\mathrm{CO}_{2}$ for synthesizing important aryl acetic acids under mild conditions. The only byproduct in this reaction is $\mathrm{N}_{2}$ while overall a high atom efficiency is realized displaying significant advantages in carboxylations. Besides aldehyde hydrazones, a variety of ketone hydrazones, which have not been successfully applied in previous umpolung reactions with other reactive electrophiles, also show high reactivity and selectivity in this reaction. This methodology displays a broad substrate scope, functional group tolerance, scalability and easy derivation of important structures. With a deeper understanding of this reaction, DFT calculations reveal the fundamental of this transformation with the generation of a Ru-nitrenoid and intermolecular $[4+2]$ cycloaddition with $\mathrm{CO}_{2}$.

\section{Conflicts of interest}

\section{Acknowledgements}

We thank Prof. Xiaofeng Wu (Leibniz-Institut für Katalyse) and Prof. Chao Liu (Lanzhou Institute of Chemical Physics) for reproducing the results. We thank Prof. Jason J. Chruma (Sichuan University) and Prof. Bi-Jie Li (Tsinghua University) for helpful manuscript revisions. We thank the National Natural Science Foundation of China (21502124, 21772020, and 21372266), the "973" Project from the MOST of China (2015CB856600), the Recruitment Program of Global Experts (Short-Term B for C. -J. Li and Young Talents for D. -G. Yu) and the Fundamental Research Funds for the Central Universities for financial support. 


\section{Notes and references}

1 (a) M. Aresta, Carbon Dioxide as Chemical Feedstock, WileyVCH, Weinheim, 2010; (b) L. Ackermann, Angew. Chem., Int. Ed., 2011, 50, 3842.

2 (a) T. Sakakura, J.-C. Choi and H. Yasuda, Chem. Rev., 2007, 107, 2365; (b) K. Huang, C.-L. Sun and Z.-J. Shi, Chem. Soc. Rev., 2011, 40, 2435; (c) M. Cokoja, C. Bruckmeier, B. Rieger, W. A. Herrmann and F. E. Kühn, Angew. Chem., Int. Ed., 2011, 50, 8510; (d) Y. Tsuji and T. Fujihara, Chem. Commun., 2012, 48, 9956; (e) M. He, Y. Sun and B. Han, Angew. Chem., Int. Ed., 2013, 52, 9620; $(f)$ L. Zhang and Z. Hou, Chem. Sci., 2013, 4, 3395; (g) M. Aresta, A. Dibenedetto and A. Angelini, Chem. Rev., 2014, 114, 1709; (h) C. Maeda, Y. Miyazaki and T. Ema, Catal. Sci. Technol., 2014, 4, 1482; (i) C. S. Yeung and V. M. Dong, Top. Catal., 2014, 57, 1342; (j) Q. Liu, L. Wu, R. Jackstell and M. Beller, Nat. Commun., 2015, 6, 5933; (k) Z. Zhang, T. Ju, J.-H. Ye and D.-G. Yu, Synlett, 2017, 28, 741.

3 For reviews, see: (a) M. Börjesson, T. Moragas, D. Gallego and R. Martin, ACS Catal., 2016, 6, 6739; (b) S. Wang, G. Du and C. Xi, Org. Biomol. Chem., 2016, 14, 3666; (c) Q. Zhu, L. Wang, C. Xia and C. Liu, Chin. J. Org. Chem., 2016, 36, 2813; (d) Q.-W. Song, Z.-H. Zhou and L.-N. He, Green Chem., 2017, 19, 3707; (e) W. Zhang, N. Zhang, C. Guo and X. Lu, Chin. J. Org. Chem., 2017, 37, 1309; (f) X.-F. Wu and F. Zheng, Top. Curr. Chem., 2017, 375, 4; (g) J. Luo and I. Larrosa, ChemSusChem, 2017, 10, 3317; (h) Y.-Y. Gui, W.-J. Zhou, J.-H. Ye and D.-G. Yu, ChemSusChem, 2017, 10, 1337; (i) A. Tortajada, F. Juliá-Hernández, M. Börjesson, T. Moragas and R. Martin, Angew. Chem., Int. Ed., 2018, DOI: 10.1002/ anie. 201803186.

4 For selected examples of carboxylation of electrophiles with $\mathrm{CO}_{2}$, see: (a) A. Correa and R. Martin, J. Am. Chem. Soc., 2009, 131, 15974; (b) T. Fujihara, K. Nogi, T. Xu, J. Terao and Y. Tsuji, J. Am. Chem. Soc., 2012, 134, 9106; (c) H. Tran-Vu and O. Daugulis, ACS Catal., 2013, 3, 2417; (d) T. Moragas, J. Cornella and R. Martin, J. Am. Chem. Soc., 2014, 136, 17702; (e) Y. Liu, J. Cornella and R. Martin, J. Am. Chem. Soc., 2014, 136, 11212; (f) K. Nogi, T. Fujihara, J. Terao and Y. Tsuji, Chem. Commun., 2014, 50, 13052; (g) X. Wang, Y. Liu and R. Martin, J. Am. Chem. Soc., 2015, 137, 6476; (h) K. Nogi, T. Fujihara, J. Terao and Y. Tsuji, J. Org. Chem., 2015, 80, 11618; (i) T. Mita, Y. Higuchi and Y. Sato, Chem.Eur. J., 2015, 21, 16391; (j) M. Börjesson, T. Moragas and R. Martin, J. Am. Chem. Soc., 2016, 138, 7504; (k) F. JuliáHernández, T. Moragas, J. Cornella and R. Martin, Nature, 2017, 545, 84; (l) K. Shimomaki, K. Murata, R. Martin and N. Iwasawa, J. Am. Chem. Soc., 2017, 139, 9467; $(\mathrm{m})$ Q.-Y. Meng, S. Wang and B. König, Angew. Chem., Int. Ed., 2017, 56, 13426.

5 For selected examples of carboxylation of nucleophiles with $\mathrm{CO}_{2}$, see: (a) M. Shi and K. M. Nicholas, J. Am. Chem. Soc., 1997, 119, 5057; (b) K. Ukai, M. Aoki, J. Takaya and N. Iwasawa, J. Am. Chem. Soc., 2006, 128, 8706; (c) T. Ohishi, M. Nishiura and Z. Hou, Angew. Chem., Int. Ed.,
2008, 47, 5792; (d) H. Ochiai, M. Jang, K. Hirano, H. Yorimitsu and K. Oshima, Org. Lett., 2008, 10, 2681; (e) C. S. Yeung and V. M. Dong, J. Am. Chem. Soc., 2008, 130, 7826; (f) L. Zhang, J. Cheng, T. Ohishi and Z. Hou, Angew. Chem., Int. Ed., 2010, 49, 8670; (g) I. I. F. Boogaerts and S. P. Nolan, J. Am. Chem. Soc., 2010, 132, 8858; (h) O. Vechorkin, N. Hirt and X. Hu, Org. Lett., 2010, 12, 3567; (i) K. Nemoto, H. Yoshida, N. Egusa, N. Morohashi and T. Hattori, J. Org. Chem., 2010, 75, 7855; (j) H. Mizuno, J. Takaya and N. Iwasawa, J. Am. Chem. Soc., 2011, 133, 1251; (k) Z. Xin, C. Lescot, S. D. Friis, K. Daasbjerg and T. Skrydstrup, Angew. Chem., Int. Ed., 2015, 54, 6862; (l) W.-Y. Gao, H. Wu, K. Leng, Y. Sun and S. Ma, Angew. Chem., Int. Ed., 2016, 55, 5472; (m) A. Banerjee, G. R. Dick, T. Yoshino and M. W. Kanan, Nature, 2016, 531, 215; (n) S. Fenner and L. Ackermann, Green Chem., 2016, 18, 3804; (o) J. Luo, S. Preciado, P. Xie and I. Larrosa, Chem.-Eur. J., 2016, 22, 6798; (p) K. Michigami, T. Mita and Y. Sato, J. Am. Chem. Soc., 2017, 139, 6094.

6 (a) A. L. Blobaum and L. J. Marnett, J. Biol. Chem., 2007, 282, 16379; (b) J. E. Milne, T. Storz, J. T. Colyer, O. R. Thiel, M. Dilmeghani Seran, R. D. Larsen and J. A. Murry, J. Org. Chem., 2011, 76, 9519; (c) R. D. Grigg, J. W. Rigoli, R. Van Hoveln, S. Neale and J. M. Schomaker, Chem.-Eur. J., 2012, 18, 9391.

7 For selected examples, see: (a) H. L. Finkbeiner and G. D. Cooper, J. Org. Chem., 1962, 27, 3395; (b) C. M. Williams, J. B. Johnson and T. Rovis, J. Am. Chem. Soc., 2008, 130, 14936; (c) M. D. Greenhalgh and S. P. Thomas, J. Am. Chem. Soc., 2012, 134, 11900; (d) P. Shao, S. Wang, C. Chen and C. Xi, Org. Lett., 2016, 18, 2050; (e) S. Kawashima, K. Aikawa and K. Mikami, Eur. J. Org. Chem., 2016, 2016, 3166; (f) K. Murata, N. Numasawa, K. Shimomaki, J. Takaya and N. Iwasawa, Chem. Commun., 2017, 53, 3098; $(g)$ V. R. Yatham, Y. Shen and R. Martin, Angew. Chem., Int. Ed., 2017, 56, 10915; (h) M. Gaydou, T. Moragas, F. Juliá-Hernández and R. Martin, J. Am. Chem. Soc., 2017, 139, 12161.

8 (a) T. León, A. Correa and R. Martin, J. Am. Chem. Soc., 2013, 135, 1221; (b) A. Correa, T. León and R. Martin, J. Am. Chem. Soc., 2014, 136, 1062; (c) S. Zhang, W.-Q. Chen, A. Yu and L.-N. He, ChemCatChem, 2015, 7, 3972; (d) T. Moragas, M. Gaydou and R. Martin, Angew. Chem., Int. Ed., 2016, 55, 5053.

9 L. Wu, Q. Liu, I. Fleischer, R. Jackstell and M. Beller, Nat. Commun., 2014, 5, 3091.

10 (a) D. Seebach, Angew. Chem., Int. Ed., 1979, 18, 239; (b) N. Marion, S. Díez-González and S. P. Nolan, Angew. Chem., Int. Ed., 2007, 46, 2988; (c) X. Bugaut and F. Glorius, Chem. Soc. Rev., 2012, 41, 3511; (d) D. M. Flanigan, F. RomanovMichailidis, N. A. White and T. Rovis, Chem. Rev., 2015, 115, 9307.

11 (a) T. Mita, J. Chen, M. Sugawara and Y. Sato, Angew. Chem., Int. Ed., 2011, 50, 1393; (b) T. Mita, J. Chen, M. Sugawara and Y. Sato, Org. Lett., 2012, 14, 6202; (c) T. Mita, M. Sugawara, H. Hasegawa and Y. Sato, J. Org. Chem., 2012, 77, 2159; (d) T. Mita, Y. Higuchi and Y. Sato, Chem.-Eur. J., 2013, 19, 
1123; (e) A. A. Sathe, D. R. Hartline and A. T. Radosevich, Chem. Commun., 2013, 49, 5040; (f) T. Mita, Y. Higuchi and Y. Sato, Org. Lett., 2014, 16, 14; $(g)$ T. Mita, J. Chen and Y. Sato, Org. Lett., 2014, 16, 2200; $(h)$ T. Mita, M. Sugawara, K. Saito and Y. Sato, Org. Lett., 2014, 16, 3028; (i) C.-X. Guo, W.-Z. Zhang, H. Zhou, N. Zhang and X.-B. Lu, Chem.-Eur. J., 2016, 22, 17156.

12 S. Sun, J. T. Yu, Y. Jiang and J. Cheng, J. Org. Chem., 2015, 80, 2855.

13 (a) W.-J. Yoo and C.-J. Li, Adv. Synth. Catal., 2008, 350, 1503;

(b) Z. Zhang, L.-L. Liao, S.-S. Yan, L. Wang, Y.-Q. He, J.-H. Ye, J. Li, Y.-G. Zhi and D.-G. Yu, Angew. Chem., Int. Ed., 2016, 55, 7068; (c) J.-H. Ye, L. Song, W.-J. Zhou, T. Ju, Z.-B. Yin, S.-S. Yan, Z. Zhang, J. Li and D.-G. Yu, Angew. Chem., Int. Ed., 2016, 55, 10022; (d) Z. Zhang, T. Ju, M. Miao, J.-L. Han, Y.-H. Zhang, X.-Y. Zhu, J.-H. Ye, D.-G. Yu and Y.-G. Zhi, Org. Lett., 2017, 19, 396; (e) Y.-Y. Gui, N. Hu, X.-W. Chen, L.-L. Liao, T. Ju, J.-H. Ye, Z. Zhang, J. Li and D.-G. Yu, J. Am. Chem. Soc., 2017, 139, 17011; (f) J.-H. Ye, M. Miao, H. Huang, S.-S. Yan, Z.-B. Yin, W.-J. Zhou and D.-G. Yu, Angew. Chem., Int. Ed., 2017, 56, 15416; $(g)$ J.-H. Ye, L. Zhu, S.-S. Yan, M. Miao, X.-C. Zhang, W.-J. Zhou, J. Li, Y. Lan and D.-G. Yu, ACS Catal., 2017, 7, 8324; (h) Z.-B. Yin, J.-H. Ye, W.-J. Zhou, Y.-H. Zhang, L. Ding, Y.-Y. Gui, S.-S. Yan, J. Li and D.-G. Yu, Org. Lett., 2018, 20, 190; (i) L. Zhu, J.-H. Ye, M. Duan, X. Qi, D.-G. Yu, R. Bai and Y. Lan, Org. Chem. Front., 2018, 5, 633; (j) Z. Zhang, C.-J. Zhu, M. Miao, J.-L. Han, T. Ju, L. Song, J.-H. Ye, J. Li and D.-G. Yu, Chin. J. Chem., 2018, 36, 430; (k) L. Sun, J.-H. Ye, W.-J. Zhou, X. Zeng and D.-G. Yu, Org. Lett., 2018, DOI: 10.1021/acs.orglett.8b01079; $(l)$ G. Shen,
W.-J. Zhou, X.-B. Zhang, G.-M. Cao, Z. Zhang, J.-H. Ye, L.-L. Liao, J. Li and D.-G. Yu, Chem. Commun., 2018, DOI: 10.1039/C8CC03039A.

14 (a) H. Wang, X.-J. Dai and C.-J. Li, Nat. Chem., 2016, 9, 374; (b) N. Chen, X.-J. Dai, H. Wang and C.-J. Li, Angew. Chem., Int. Ed., 2017, 56, 6260; (c) X.-J. Dai, H. Wang and C.-J. Li, Angew. Chem., Int. Ed., 2017, 56, 6302; (d) W. Wei, X.-J. Dai, H. Wang, C. Li, X. Yang and C.-J. Li, Chem. Sci., 2017, 8, 8193.

15 M. E. Furrow and A. G. Myers, J. Am. Chem. Soc., 2004, 126, 5436 and references therein.

16 (a) G. Spitzmaul, F. Gumilar, J. P. Dilger and C. Bouzat, Br. J. Pharmacol., 2009, 157, 804; (b) P. Urbani, M. G. Cascio, A. Ramunno, T. Bisogno, C. Saturnino and V. D. Marzo, Bioorg. Med. Chem., 2008, 16, 7510; (c) G. Autore, A. Caruso, S. Marzocco, B. Nicolaus, C. Palladino, A. Pinto, A. Popolo, M. S. Sinicropi, G. Tommonaro and C. Saturnino, Molecules, 2010, 15, 2028; (d) B. Ma, Z. Chu, B. Huang, Z. Liu, L. Liu and J. Zhang, Angew. Chem., Int. Ed., 2017, 56, 2749.

17 (a) J. L. Jat, M. P. Paudyal, H. Gao, Q.-L. Xu, M. Yousufuddin, D. Devarajan, D. H. Ess, L. Kurti and J. R. Falck, Science, 2014, 343, 61; (b) V. Bizet, L. Buglioni and C. Bolm, Angew. Chem., Int. Ed., 2014, 53, 5639; (c) Y. Lin, L. Zhu, Y. Lan and Y. Rao, Chem.-Eur. J., 2015, 21, 14937.

18 The activation free energy of cycloaddition between aminoruthenium $\mathbf{C}$ and $\mathrm{CO}_{2}$ is up to $38.1 \mathrm{kcal} \mathrm{mol}^{-1}$ (Fig. S3†), which suggests that the second $\mathrm{N}-\mathrm{H}$ bond cleavage would be preferentially occur from amino-ruthenium $\mathbf{C}$.

19 For more computational details, please see in ESI. $\dagger$

20 A. E. Reed, L. A. Curtiss and F. Weinhold, Chem. Rev., 1988, 88, 899. 